\title{
Analisa faktor-faktor yang berhubungan dengan pemberian ASI eksklusif Di wilayah kerja Puskesmas Prabumulih Timur Kota Prabumulih Tahun 2021
}

\author{
Desi Ratnasari*, Sendy Pratiwi Rahmadhani, Tuti Farida, Siti Aisyah \\ S1 Kebidanan, Universitas Kader Bangsa Palembang \\ *Correspondence email: desiiratnasari7@gmail.com, sandy.pratiwi.01@gmail.com
}

\begin{abstract}
Abstrak. ASI eksklusif diberikan pada bayi berumur 0-6 bulan, karena nutrisi terbaik bagi bayi hanya diperoleh melalui ASI (WHO, 2020). Menurut data Word Health Organization (WHO) cakupan ASI eksklusif di seluruh dunia hanya sekitar 44 persen selama periode 2015-2020. Berdasarkan data dari profil kesehatan Indonesia tahun 2019 menyatakan bahwa persentase cakupan pemberian ASI eksklusif di Indonesia pada bayi 0-6 bulan adalah 67,74 persen. Cakupan ASI eksklusif di Kota Prabumulih tahun 2019 65,8 persen. Hasil studi pendahuluan di Puskesmas Prabumulih Timur cakupan ASI eksklusif hanya 43,1 persen. Tujuan dari penelitian ini adalah untuk mengetahui hubungan paritas dan proses persalinan dengan pemberian ASI eksklusif di wilayah kerja Puskesmas Prabumulih Timur Kota Prabumulih Tahun 2021. Jenis penelitian ini menggunakan metode survey analitik dengan desain cross sectional. Populasi pada penelitian ini adalah ibu yang memiliki anak usia 7-12 bulan di wilayah kerja Puskesmas Prabumulih Timur Kota Prabumulih berjumlah 355 orang. besar sampel ditentukan dengan rumus slovin, dan didapatkan hasil sebesar 78 responden. Sampel di ambil dengan menggunakan teknik propotional random sampling. Data dianalisis dengan uji statistik chi-square. Hasil penelitian menunjukkan bahwa dari 78 responden. Didapatkan yang memberikan ASI eksklusif sebesar $38(48,7 \%)$ dan yang tidak memberikan ASI eksklusif sebesar 40 (51,3\%), tingkat pendidikan rendah $44(56,4 \%)$ dan pendidikan tinggi 34 (43,6\%), Status ibu yang bekerja $44(56,4 \%)$ dan ibu tidak bekerja $34(43,6 \%)$, paritas rendah 30 (38,5\%) dan paritas tinggi 48 (61,5\%), persalinan normal 59 (75,6\%) dan persalinan SC 19 (24,4\%). hasil chi-square 4 (empat) variabel yang bermakna dengan nilai $p$-value $<0,05$ yaitu variabel tingkat pendidikan $p$-value $=0,000, \mathrm{OR}=0,151(95 \% \mathrm{CI}=0,056-0,410)$, status pekerjaan $p$-value $=0,002, \mathrm{OR}=0,194(95 \% \mathrm{CI}=0,073-0,514)$, jumlah paritas dengan nilai $p$-value $=0,023, \mathrm{OR}=3,333$ $(95 \% \mathrm{CI}=1,279-8,688)$, proses persalinan dengan nilai $p$-value $=0,012, \mathrm{OR}=5,100(95 \% \mathrm{CI}=1,509-17,237) . \mathrm{Kesimpulan}$ dalam penelitian ini adalah ada hubungan paritas dan proses persalinan secara stimultan dengan pemberian ASI eksklusif di wilayah kerja Puskesmas Prabumulih Timur Kota Prabumulih Tahun 2021. Disarankan kepada masyarakat untuk memberikan ASI eksklusif kepada bayinya demi mencegah angka kesakitan pada bayi.
\end{abstract}

Kata kunci: ASI eksklusif; tingkat pendidikan; status pekerjaan; paritas; proses persalinan.

Abstract. Exclusive breastfeeding is given to infants aged 0-6 months, because the best nutrition for babies is only obtained through breast milk (WHO, 2020). According to data from the World Health Organization (WHO) worldwide exclusive breastfeeding coverage is only around 44 percent during the 2015-2020 period. Based on data from the 2019 Indonesian health profile, it is stated that the percentage of exclusive breastfeeding coverage in Indonesia for infants 0-6 months is 67.74 percent. Exclusive breastfeeding coverage in Prabumulih City in 2019 was 65.8 percent. The results of a preliminary study at the Prabumulih Timur Health Center covered only 43.1 percent of exclusive breastfeeding. The results showed that from 78 respondents. It was found that those who gave exclusive breastfeeding were 38 (48.7\%) and those who did not gave exclusive breastfeeding were 40 (51.3\%), low level of education 44 (56.4\%) and higher education 34 (43.6\%). working mothers 44 (56.4\%) and mothers who did not work 34 (43.6\%), low parity 30 (38.5\%) and high parity 48 (61.5\%), normal delivery 59 (75.6\% ) and CS 19 delivery (24.4\%). chi-square results 4 (four) significant variables with p-value $<0.05$, namely education level variable $p$ value $=0.013, O R=0.280(95 \% C I=0.109-0.714)$, employment status $p$-value $=0.002$, OR $=0.193(95 \% C I=0.073-0.514)$, parity with $p$-value $=0.023, O R=3.333(95 \% C I=1.279-8.688)$, delivery process with -value $=0.012, O R=5.100(95 \% C I=$ 1,509-17,237). The conclusion in this study is that there is a relationship between parity and the process of giving birth simultaneously with exclusive breastfeeding in the working area of the Prabumulih Timur Health Center, Prabumulih City in 2021. It is recommended that the community give exclusive breastfeeding to their babies in order to prevent infant morbidity.

Keywords: Exclusive breastfeeding; level of education; job status; parity; childbirth process.

\section{PENDAHULUAN}

Nutrisi merupakan salah satu faktor yang dapat mendukung kesehatan anak. Nutrisi terbaik bagi bayi adalah air susu ibu (ASI). Nutrisi terbaik diberikan pada bayi nol sampai enam bulan kemudian dilanjutkan dua tahun pertama kehidupan karena bisa menurunkan angka morbiditas dan mortalitas. Cakupan ASI Eksklusif secara Global pada periode tahun 2015 sampai 2020 hanya 44 persen. Seratus empat pulih sembilan juta (149) anak mengalami stunting (masalah kurang gizi kronis akibat kurangnya asupan gizi dalam waktu yang lama sehingga mengalami gangguan pertumbuhan pada anak). Empat puluh lima (45) juta anak mengalami kurus (terlalu kurus dan tinggi yang tidak sesuai dengan usia), dan 38,9 juta anak mengalami obesitas (berat badan berlebih). Pemberian ASI bisa menyelamatkan 820.000 
Desi Ratnasari et al., Analisa faktor-faktor yang berhubungan dengan pemberian ASI eksklusif Di wilayah kerja Puskesmas Prabumulih Timur Kota Prabumulih Tahun 2021

nyawa anak di bawah 5 tahun jika diberikan secara optimal (WHO, 2020; Infodatin, 2018).

Secara global di Negara Afrika Sub-Sahara dari tahun 2000 sampai 2018 mengalami 5,3 juta jiwa anak meninggal di bawah umur 5 tahun. Negara Afrika SubSahara adalah negara yang mengalami kematian balita tertinggi secara Global. Di negara tersebut pada periode tahun 2000 sampai 2018 telah membuktikan bahwa pemberian ASI secara Eksklusif bisa menurunkan angka kematian anak. Prevalensi pemberian ASI eksklusif 1 persen dapat menurunkan angka kematian yang sangat signifikan 3,4 per 1000 anak. United Nations Children's Fund (UNICEF) telah merekomendasikan pemberian ASI eksklusif pada 6 bulan pertama kehidupan.

Cakupan ASI eksklusif menurut data Profil Kesehatan Indonesia pada tahun 2019 adalah sebesar 67,74 persen. Data tersebut sudah melampaui batas target Renstra tahun 2019 yaitu 50 persen tetapi belum mencapai target Nasional yaitu 80 persen. Cakupan ASI eksklusif persentase tertinggi terdapat pada Provinsi Nusa Tenggara Barat 82,26 persen, dan cakupan ASI eksklusif terendah terdapat pada Provinsi Papua Barat 41,12 persen. Cakupan ASI eksklusif di Sumatera Selatan masih tergolong rendah dari provinsi yang lain walaupun telah mencapai target Renstra dengan cakupan ASI eksklusif 57,79 persen (Profil Kesehatan Indonesia, 2019).

Cakupan ASI eksklusif di Kota Prabumulih tahun 2018 adalah 76,3 persen. Pada tahun 2019 mengalami penurunan menjadi 65,8 persen. Cakupan ASI eksklusif tertinggi terdapat di Puskesmas Pasar dengan capaian 83,5 persen dan cakupan terendah pada Puskesmas Timur dengan capaian 43,1 persen.

Berdasarkan hasil studi pendahuluan di Puskesmas Timur Kota Prabumulih pada tahun 2020 bayi yang mendapatkan ASI eksklusif adalah 152 dari 227 kelahiran $(67,4$ persen) wilayah kerja Puskesmas Timur Kota Prabumulih Terdapat Tiga Kelurahan/Desa di 3 kelurahan tersebut adalah (Kelurahan Gunung Ibul, Kelurahan Gunung Ibul Barat dan Desa Karang Raja). Berdasarkana data yang di dapat membuktikan cakupan ASI eksklusif yang masih rendah menjadi masalah di Puskesmas Timur Kota Prabumulih (Puskesmas Timur, 2019).

\section{METODE}

Jenis penelitian ini menggunakan metode survey Analitik dengan pendekatan Cross sectional. Penentuan Sampel penelitian ini adalah ibu yang mempunyai bayi usia 7-12 bulan yang ada diwilayah kerja puskesmas prabumulih timur kota prabumulih tahun 2021, yang memenuhi syarat sesuai kriteria inklusi dan eklusi. Analisa data menggunakan uji chi-square.

\section{HASIL DAN PEMBAHASAN}

Berdasarkan dari 78 responden didapatkan hasil, didapatkan hasil analisa univarat dan analisa bivariat :

\section{Analisis univariat}

Tabel 1. Distribusi Frekuensi Responden Berdasarkan Pemberian ASI Eksklusif

\begin{tabular}{lcc}
\hline \multicolumn{1}{c}{ ASI Eksklusif } & Frekuensi & \% \\
\hline Tidak & 40 & 51,3 \\
Ya & 38 & 48,7 \\
Total & $\mathbf{7 8}$ & $\mathbf{1 0 0}$ \\
\hline
\end{tabular}

Dari tabel 1. dapat dilihat dari 78 responden, terdapat $40(50,1 \%)$ responden tidak memberikan ASI eksklusif dan $38(48,7 \%)$ responden memberikan ASI eksklusif.

Tabel 2. Distribusi Frekuensi Responden Berdasarkan tingkat pendidikan

\begin{tabular}{lcc}
\hline Tingkat Pendidikan & Frekuensi & \% \\
\hline Rendah & 44 & 56,4 \\
Tinggi & 34 & 43,6 \\
Total & $\mathbf{7 8}$ & $\mathbf{1 0 0}$ \\
\hline
\end{tabular}

Dari tabel 2. dapat dilihat dari 78 responden, terdapat $44(56,4 \%)$ responden tingkat pendidikan rendah dan $34(43,6 \%)$ responden tingkat pendidikan tinggi.

Tabel 3. Distribusi Frekuensi Responden Berdasarkan status pekerjaan

\begin{tabular}{lcc}
\hline Status Pekerjaan & Frekuensi & \% \\
\hline Bekerja & 44 & 56,4 \\
Tidak Bekerja & 34 & 43,6 \\
Total & $\mathbf{7 8}$ & $\mathbf{1 0 0}$ \\
\hline
\end{tabular}

Dari tabel 3. dapat dilihat dari 78 responden, terdapat $44(56,4 \%)$ responden status bekerja rendah dan $34(43,6 \%)$ responden status tidak bekerja.

Tabel 4. Distribusi Frekuensi Responden Berdasarkan paritas

\begin{tabular}{lcc}
\multicolumn{1}{c}{ Paritas } & Frekuensi & \% \\
\hline Rendah & 30 & 38,5 \\
Tinggi & 48 & 61,5 \\
Total & $\mathbf{7 8}$ & $\mathbf{1 0 0}$ \\
\hline
\end{tabular}

Dari tabel 4 dapat dilihat 78 responden, terdapat $30(38,5 \%)$ responden paritas rendah dan $48(61,5 \%)$ responden paritas tinggi.

Tabel 5. Distribusi Frekuensi Responden Berdasarkan proses persalinan

\begin{tabular}{lcc}
\hline Proses Persalinan & Frekuensi & \% \\
\hline Normal & 59 & 75,6 \\
Tindakan & 19 & 24,4 \\
Total & $\mathbf{7 8}$ & $\mathbf{1 0 0}$ \\
\hline
\end{tabular}

Dari tabel 5, dapat dilihat 78 responden, terdapat $59(75,6 \%)$ responden persalinan normal dan $19(24,4 \%)$ responden persalinan tindakan. 
Desi Ratnasari et al., Analisa faktor-faktor yang berhubungan dengan pemberian ASI eksklusif Di wilayah kerja Puskesmas Prabumulih Timur Kota Prabumulih Tahun 2021

\section{Analisis bivariat}

Analisis bivariat dilakukan untuk mengetahui hubungan antara variabel independen (tingkat pendidikan, status pekerjaan, paritas dan proses persalinan) dengan variabel dependen (pemberian ASI eksklusif).

Tabel 6. Hubungan tingkat pendidikan dengan pemberian ASI eksklusif di wilayah kerja Puskemas Prabumulih Timur Kota Prabumulih Tahun 2021

\begin{tabular}{|c|c|c|c|c|c|c|c|c|c|}
\hline \multirow{3}{*}{ No } & \multirow{3}{*}{$\begin{array}{c}\text { Tingkat } \\
\text { Pendidikan }\end{array}$} & \multicolumn{4}{|c|}{ ASI Ekslusif } & \multirow{3}{*}{ Total } & \multirow{3}{*}{$\%$} & \multirow{3}{*}{ p-value } & \multirow{3}{*}{ OR } \\
\hline & & \multicolumn{2}{|c|}{ Ya } & \multicolumn{2}{|c|}{ Tidak } & & & & \\
\hline & & $\mathbf{n}$ & $\%$ & $\mathbf{n}$ & $\%$ & & & & \\
\hline 1 & Rendah & 13 & 29,5 & 31 & 70,5 & 44 & 100 & \multirow{3}{*}{0,000} & \multirow{3}{*}{$3,333(1,279-8,688)$} \\
\hline 2 & Tinggi & 25 & 73,5 & 9 & 26,5 & 34 & 100 & & \\
\hline & Total & & & & & 78 & 100 & & \\
\hline
\end{tabular}

Dari tabel 6 diatas menunjukkan bahwa dari 78 responden. Terdapat 44 responden pendidikan rendah, $13(29,6 \%)$ responden pendidikan rendah memberikan ASI eksklusif dan $31(70,5 \%)$ responden pendidikanr rendah tidak memberikan ASI eksklusif. Terdapat 34 responden pendidikan tinggi, 25 (73,5\%) responden pendidikan tinggi memberikan ASI eksklusif dan 9 $(26,5 \%)$ responden pendidikan tinggi tidak memberikan ASI eksklusif.
Hasil uji chi-square di peroleh nilai $p$-value 0,000 $>\alpha 0,05$, artinya ada hubungan yang bermakna tingkat pendidikan dengan dengan pemberian ASI eksklusif. Bearti hipotesis yang menyatakan ada hubungn antara tingkat pendidikan secara parsial dengan pemberian ASI eksklusif terbukti secara statistik. Nilai odds Ratio (OR) $0,151 \quad(95 \% \mathrm{CI}=0,056-0,410)$ menunjukkan bahwa tingkat pendidikan tinggi lebih berpengaruh 0,151 kali lipat akan memberikan ASI eksklusif dari pada ibu tingkat pendidikan rendah.

Tabel 7. Hubungan status pekerjaan dengan pemberian ASI eksklusif di wilayah kerja Puskemas Prabumulih Timur Kota Prabumulih Tahun 2021

\begin{tabular}{|c|c|c|c|c|c|c|c|c|c|}
\hline \multirow{3}{*}{ No } & \multirow{3}{*}{ Status Pekerjaan } & \multicolumn{4}{|c|}{ ASI Ekslusif } & \multirow{3}{*}{ Total } & \multirow{3}{*}{$\%$} & \multirow{3}{*}{ p-value } & \multirow{3}{*}{ OR } \\
\hline & & \multicolumn{2}{|c|}{ Ya } & \multicolumn{2}{|c|}{ Tidak } & & & & \\
\hline & & $\mathbf{n}$ & $\%$ & $\mathbf{n}$ & $\%$ & & & & \\
\hline 1 & Bekerja & 14 & 31,8 & 30 & 68,2 & 44 & 100 & 0007 & $3333(1270-8688)$ \\
\hline 2 & Tidak Bekerja & 24 & 70,6 & 10 & 29,4 & 34 & 100 & 0,002 & (1, \\
\hline & Total & & & & & 78 & 100 & & \\
\hline
\end{tabular}

Dari tabel 7 diatas menunjukkan bahwa dari 78 responden. Terdapat 44 responden status ibu bekerja, 14 $(31,6 \%)$ responden bekerja memberikan ASI eksklusif dan $30(68,2 \%)$ responden ibu bekerja tidak memberikan ASI eksklusif. Terdapat 34 responden tidak bekerja 24 $(70,6 \%)$ responden tidak bekerja memberikan ASI eksklusif dan $10(29,4 \%)$ responden tidak bekerja tidak memberikan ASI eksklusif.
Hasil uji chi-square di peroleh nilai p-value 0,002 $>\alpha 0,05$, artinya ada hubungan yang bermakna status pekerjaan dengan dengan pemberian ASI eksklusif. Bearti hipotesis yang menyatakan ada hubungn antara status pekerjaan secara parsial dengan pemberian ASI eksklusif terbukti secara statistik. Nilai odds Ratio (OR) 0,194 (95\% CI=0,073-0,514), menunjukkan bahwa ibu bekerja tinggi lebih berpengaruh 0,194 kali lipat akan memberikan ASI eksklusif dari pada ibu tidak bekerja.

Tabel 8. Hubungan paritas dengan pemberian ASI eksklusif di wilayah kerja Puskemas Prabumulih Timur Kota Prabumulih Tahun 2021

\begin{tabular}{|c|c|c|c|c|c|c|c|c|c|}
\hline \multirow{3}{*}{ No } & \multirow{3}{*}{ Paritas } & \multicolumn{4}{|c|}{ ASI Ekslusif } & \multirow{3}{*}{ Total } & \multirow{3}{*}{$\%$} & \multirow{3}{*}{ p-value } & \multirow{3}{*}{ OR } \\
\hline & & \multicolumn{2}{|c|}{ Ya } & \multicolumn{2}{|c|}{ Tidak } & & & & \\
\hline & & $\mathbf{n}$ & $\%$ & $\mathbf{n}$ & $\%$ & & & & \\
\hline 1 & Rendah & 20 & 66,7 & 10 & 33,3 & 30 & 100 & 0023 & (2000 \\
\hline 2 & Tinggi & 18 & 37,5 & 30 & 62,5 & 48 & 100 & 0,023 & $3,333(1,2 / 9-8,688)$ \\
\hline & Total & & & & & 78 & 100 & & \\
\hline
\end{tabular}

Dari tabel 8 dapat dilihat dari 78 responden, terdapat paritas rendah 30 responden, $20(66,7 \%)$ ibu paritas rendah memberikan ASI eksklusif dan 10 (33,3\%) ibu paritas rendah tidak memberikan ASI eksklusif. Ibu paritas tinggi 48 responden $18(37,5 \%) \mathrm{ibu}$ paritas tinggi memberikan ASI eksklusif dan 30 (62,5\%) ibu paritas tinggi tidak memberikan ASI eksklusif.

Hasil uji chi-square di peroleh nilai p-value 0,023 $>\alpha 0,05$, artinya ada hubungan yang bermakna paritas dengan dengan pemberian ASI eksklusif. Bearti hipotesis yang menyatakan ada hubungn antara paritas 
Desi Ratnasari et al., Analisa faktor-faktor yang berhubungan dengan pemberian ASI eksklusif Di wilayah kerja Puskesmas Prabumulih Timur Kota Prabumulih Tahun 2021

secara parsial dengan pemberian ASI eksklusif terbukti secara statistik. Nilai odds Ratio (OR) 3,333 (95\% CI= 1,279-8,688), menunjukkan bahwa ibu paritas rendah lebih berpengaruh 3,333 kali lipat akan memberikan ASI eksklusif dari pada ibu paritas tinggi

Tabel 9. Hubungan proses persalinan dengan pemberian ASI eksklusif di wilayah kerja Puskemas Prabumulih Timur Kota Prabumulih Tahun 2021

\begin{tabular}{|c|c|c|c|c|c|c|c|c|c|}
\hline \multirow{3}{*}{ No } & \multirow{3}{*}{ Proses Persalinan } & \multicolumn{4}{|c|}{ ASI Ekslusif } & \multirow{3}{*}{ Total } & \multirow{3}{*}{$\%$} & \multirow{3}{*}{ p-value } & \multirow{3}{*}{$\mathbf{O R}$} \\
\hline & & \multicolumn{2}{|c|}{ Ya } & \multicolumn{2}{|c|}{ Tidak } & & & & \\
\hline & & $\mathbf{n}$ & $\%$ & $\mathbf{n}$ & $\%$ & & & & \\
\hline 1 & Normal & 34 & 57,6 & 25 & 42,4 & 59 & 100 & \multirow{3}{*}{0,012} & \multirow{3}{*}{$5,100(1,509-17,237)$} \\
\hline 2 & Tindakan & 4 & 21,1 & 15 & 78,9 & 19 & 100 & & \\
\hline & Total & & & & & 78 & 100 & & \\
\hline
\end{tabular}

Dari tabel 9 dapat dilihat dari 78 responden, terdapat ibu persalinan normal 59 responden, $34(57,8 \%)$ ibu persalinan normal memberikan ASI eksklusif dan 25 $(42,4 \%)$ persalinan normal tidak memberikan ASI eksklusif. Persalinan tindakan 19 responden, $4(21,1)$ persalinan tindakan memberikan ASI eksklusif dan 15 (78,9\%) persalinan tindakan tidak memberikan ASI eksklusif.

Hasil uji chi-square di peroleh nilai $p$-value 0,012 $>\alpha 0,05$, artinya ada hubungan yang bermakna proses persalinan dengan dengan pemberian ASI eksklusif. Bearti hipotesis yang menyatakan ada hubungn antara proses persalinan secara parsial dengan pemberian ASI eksklusif terbukti secara statistik. Nilai odds Ratio (OR) 5,100 (95\% CI=1,509-17,237). menunjukkan bahwa ibu persalinan normal lebih berpengaruh 5,100 kali lipat akan memberikan ASI eksklusif dari pada ibu proses persalinan tindakan.

\section{Pembahasan \\ Hubungan antara paritas dengan pemberian ASI eksklusif}

Hasil analisa univariat dapat dilihat dari 78 responden, ibu yang paritas rendah yaitu 30 responden $(38,5 \%)$ ibu yang paritas tinggi yaitu 48 responden $(61,5 \%)$. Hasil analisa bivariat menunjukkan bahwa dari 78 responden. Ibu yang paritas rendah ada 30 responden, ibu yang paritas rendah memberikan ASI eksklusif yaitu 20 responden $(66,7 \%)$ dan ibu paritas rendah yang tidak memberikan ASI eksklusif ada 10 responden Sedangkan dari 48 ibu yang paritas tinggi yang memberikan ASI eksklusif ada 18 responden $(37,5 \%)$ dan ibu paritas tinggi yang tidak memberikan ASI eksklusif ada 30 responden $(62,5 \%)$. Hasil uji chi-square di peroleh nilai p-value $0,023>\alpha 0,05$, artinya ada hubungan yang bermakna antara paritas ibu dengan pemberian ASI eksklusif. Nilai odds Ratio (OR) 3,333 dengan CI 95\% (1,279-8,688) menunjukkan bahwa ibu yang paritas rendah lebih berpengaruh 3,333 kali lipat akan memberikan ASI eksklusif dari pada ibu paritas tinggi.

Jumlah paritas adalah jumlah atau banyaknya persalinan yang pernah dialami ibu baik hidup maupun mati (Bobak, 2010). ASI eksklusif adalah pemberian ASI saja pada bayi 0-6 bulan tanpa pemberian cairan lain seperti susu formula, air jeruk, madu, air teh, air putih dan tanpa makanan padat lainnya (Haryono, 2014). Paritas juga sangat berpengaruh pada pemberian ASI eksklusif, Paritas yang mendukung pemberian ASI eksklusif adalah paritas tinggi karena ibu sudah memiliki pengalaman dalam pemberian ASI kepada anaknya, dan tidak ragu-ragu lagi karena sudah pernah memberikan ASI eksklusif yang memiliki banyak manfaat bagi tubuh bayi.

Penelitian Purba (2020) juga sejalan dengan penelitian diatas dengan $p$-value $0,0001<0.05$ yang bearti ada hubungan yang bermakna antara jumlah paritas dengan pemberian ASI eksklusif. ibu yang memilki paritas multipara lebih memiliki pengalaman dalam menyusui dibandingkan ibu yang memilki paritas primipara.

Penelitian ini sejalan dengan penelitian yang dilakukan (Annisa, 2018) yang mengatakan bahwa ada hubungan antara jumlah paritas dengan pemberian ASI eksklusif. Jumlah paritas multipara sudah terbiasa memberikan ASI kepada anaknya, sehingga kecil kemungkinan untuk tidak memberikan ASI eksklusif.

Penelitian yang dilakukan (Prabawati, 2017) dengan judul "multilevel analysis on the biosocial abd economic determinants of exclusive breastfeeding) mengatakan ada hubungan yang bermakna anatara jumlah paritas dengan pemberian ASI eksklusif. Dengan responden multipara lebih besar dari pada primipara. Ibu yang multipara sudah lebih paham dan berpengalaman dalam pemberian ASI eksklusif kepada bayinya.

Menurut asumsi peneliti paritas sangat mempengaruhi pemberian ASI eksklusif, pada penelitian ini ibu paritas tinggi lebih banyak dari pada ibu yang paritas rendah. Ibu yang paritas tinggi mempunyai pengalaman dalam memberikan ASI eksklusif kepada bayinya, sedangkan pada ibu yang paritas rendah masih ragu dan ASI masih sedikit yang keluar.

\section{Hubungan antara proses persalinan dengan pemberian ASI eksklusif}

Hasil analisa univariat dari 78 responden, ibu yang persalinan normal lebih banyak yaitu 59 responden (75,6\%) dibandingkan ibu yang persalinan dengan tindakan yaitu 19 responden $(62,8 \%)$. Hasil analisa 
Desi Ratnasari et al., Analisa faktor-faktor yang berhubungan dengan pemberian ASI eksklusif Di wilayah kerja Puskesmas Prabumulih Timur Kota Prabumulih Tahun 2021

bivariat dari 59 responden ibu yang proses persalinan normal dan tidak memberikan ASI eksklusif ada 25 responden $(42,4 \%)$ lebih sedikit dari ibu yang proses persalinan normal yang memberikan ASI eksklusif yaitu 34 responden (57,6\%). Sedangkan dari 19 ibu yang proses persalinan dengan tindakan yang tidak memberikan ASI eksklusif ada 15 responden $(78,9 \%)$ dan ibu yang proses persalinan dengan tindakan yang memberikan ASI eksklusif ada 4 responden $(21,1 \%)$.

Hasil uji chi-square di peroleh nilai p-value 0,012 $>\alpha 0,05$, artinya ada hubungan yang bermakna antara proses persalinan ibu dengan pemberian ASI eksklusif. Bearti hipotesis yang menyatakan ada hubungn antara status pekerjaan secara parsial dengan pemberian ASI eksklusif terbukti secara statistik. Nilai odds Ratio (OR) 0, 196 dengan CI 95\% 0,058 - 0,663 menunjukkan bahwa ibu proses persalinan normal lebih beresiko 0,300 kali lipat akan memberikan ASI eksklusif dari pada ibu proses persalinan dengan tindakan.

Hasil penelitian ini sejalan dengan hasil penelitian (Rahkmawati, 2019) mengatakan berdasarkan hasil uji statistik dengan taraf signifikan sig $\alpha 0,05$, diperoleh hasil $\rho$-value $0,001<0,05$ yang berarti ada hubungan proses persalinan dengan pemberian ASI Eksklusif di RSU Sundari Medan Tahun 2019, Persalinan secara normal memiliki kemungkinan dan keberhasilan pemberian ASI Eksklusif lebih besar dari pada ibu yang melahirkan secara SC. Karena pada persalinan normal teknik menyusui yang mudah dan proses menyusui dapat segera dilakukan setelah bayi lahir. Sedangkan ibu yang persalinannya secara SC menjadi kendala untuk memberikan ASI.

Penelitian yang juga sejalan dengan penelitian yang dilakukan Siti (2017) mengatakan pada ibu yang melahirkan di RSUD Wates Kulon Progo ( $p$-value 0,013) Proses kelahiran secara sectio cesarea juga mempengaruhi proses pengeluaran ASI, karena Ibu yang melahirkan dengan cara operasi cesar seringkali sulit menyusui bayinya segera setelah ia lahir. Terutama jika ibu diberikan anastesi umum.

Penelitian yang dilakukan di Turki (Erbaydar, 2020) dengan judul "Relationship Between Caesarea Section And Breastfeeding Turkey" mengatakan ada hubungan yang signifikan antara proses persalinan dengan pemberian ASI eksklusif. Pada persalinan SC menyebabkan efek samping menghambat kontak ibu dan bayi, mengakibatkan rasa nyeri yang tidak dapat ditoleransi dan peningkatan tingkat kebutuhan akan perawatan intesnif yang dapat mempengaruhi proses persalinan.

Persalinan merupakan pengeluaran hasil konsepsi (janin dan ari) yang telah cukup bulan atau dapat hidup di luar kandungan melalui jalan lahir atau melalui jalan lain, dengan bantuan atau tanpa bantuan (kekuatan sendiri) (Manuaba, 2010). Persalinan dibagi menjadi 2 kategori, yaitu persalinan normal dan persalinan dengan tindakan. Persalinan sangat berpengaruh pada pemberian
ASI eksklusif karena pada ibu yang post SC lebih susah dalam memberikan ASI pada saat setelah bayi lahir. Sedangkan pada ibu yang persalinan normal lebih mudah dalam memberikan ASI setelah bayinya lahir.

Menurut asumsi peneliti, Pada persalinan normal umumnya terjadi penurunan kader esterogen dan progesteron secara drastis segera setelah plasenta lahir, hasil ini memicu pengeluaran ASI. Hasil penelitian yang dilakukan peneliti ibu yang proses persalinan normal lebih besar dalam memberikan ASI eksklusif dan proses menyusui setelah bayinya lahir. Sedangkan ibu yang proses persalinan dengan tindakan ada kendala untuk memberikan ASI eksklusif terkendala pada rasa nyeri yang dialami ibu setelah SC yang membuat proses menyusui terhambat.

\section{SIMPULAN}

Dari hasil penelitian yang dilakukan di wilayah kerja Puskesmas Prabumulih Timur Kota Prabumulih Tahun 2021, dapat disimpulkan bahwa hasil penelitian ini :

1. Ada hubungan tingkat pendidikan, status pekerjaan, paritas dan proses persalinan secara stimultan dengan pemberian ASI eksklusif di Wilayah Kerja Puskesmas Prabumulih Timur Kota Prabumulih Tahun 2021.

2. Ada hubungan tingkat pendidikan secara parsial dengan pemberian ASI Eksklusif di Wilayah Kerja Puskesmas Prabumulih Timur Kota Prabumulih Tahun 2021.

3. Ada hubungan status pekerjaan secara parsial dengan pemberian ASI Eksklusif di Wilayah Kerja Puskesmas Prabumulih Timur Kota Prabumulih Tahun 2021.

4. Ada hubungan jumlah paritas secara parsial dengan pemberian ASI Eksklusif di Wilayah Kerja Puskesmas Prabumulih Timur Kota Prabumulih Tahun 2021.

5. Ada hubungan proses persalinan secara parsial dengan pemberian ASI Eksklusif di Wilayah Kerja Puskesmas Prabumulih Timur Kota Prabumulih Tahun 2021.

\section{DAFTAR PUSTAKA}

Buku Bobak, (2010). Buku Ajar Keperawatan Maternitas Edisi 4. Jakarta: EGC.

Purba Edy Marjuang, (2020). Hubungan Karakteristik Ibu Dengan Pemberian Asi Eksklusif Di Wilayah Kerja Puskesmas Korpri Kecamatan Berastagi Kabupaten Karo Tahun 2019.

Fatimah Siti, (2017). Hubungan Karakteristik Dan Pengetahuan Ibu Dengan Pemberian Asi Eksklusif Di Wilayah Kerja Puskesmas Turitahun 2017. Skripsi Fakultas Kebidanan Politeknik Kesehatan Kementerian Kesehatan.

Haryono, (2014). Pengertian ASI. Eprints.poltekesjogja.ac.id. 
Desi Ratnasari et al., Analisa faktor-faktor yang berhubungan dengan pemberian ASI eksklusif Di wilayah kerja Puskesmas Prabumulih Timur Kota Prabumulih Tahun 2021

Infodatin (2018). Menyusui sebagai dasar kehidupan. https://www.kemkes.go.id ( diakses pada tanggal 17 Juni 2021).

Khoiriah Annisa, (2018). Faktor-Faktor Yang Berpengaruh Terhadap Pemberian Asi Eksklusif Pada Bayi Berumur Dibawah 6 Bulan Di Bpm Rusmiati Okta Palembang.

Manuaba, IAC., I Bagus, dan IB Gde. 2010. Ilmu Kebidanan, Penyakit Kandungan dan KB untuk Pendidikan Bidan. Edisi kedua. Jakarta: EGC.

Nuket paksoy erbaydar (2020). elationship between caesarean section and breastfeeding: evidence from the 2013 Turkey demographic and health survey

Profil Kesehatan Indonesia. (2019). Cakupan ASI Eksklusif.

Profil Kesehatan Kota Prabumulih, (2019). Cakupan ASI Eksklusif.

Rahkmawati, (2019). Hubungan Jenis Persalinan Dan Dukungan Keluarga Dengan Pemberian Asi Eksklusif Di Rsu Sundari Medan Tahun 2019. Fakultas Farmasi Dan Kesehatan Institut Kesehatan Helvetia. Medan.

Sinta Prabawati (2017). Multilevel Analysis on the Biosocial and Economic Determinants of Exclusive Breastfeeding.

Word Health Organization, (2020). Pengertian ASI Eksklusif. 